\author{
Journal of Government and Political Studies \\ Volume 3 - NO. 1 - April 2020 \\ P-ISSN: 2614-2120 E-ISSN: 2614-2104
}

\title{
Pilkada Calon Tunggal Di Kabupaten Landak Tahun 2017
}

\author{
Ori Fahriansyah' \\ Adityo Darmawan Sudagung 2 \\ Program Studi Ilmu Politik ${ }^{1}$, FISIP Universitas Tanjungpura Pontianak \\ Program Studi Hubungan Internasiona 2 l, FISIP Universitas Tanjungpura Pontianak \\ Jl. Prof. Dr. H. Hadari Nawawi, Pontianak Tenggara, 78124 \\ adityo.ds@fisip.untan.ac.id
}

Received:February 17, 2020; Revised:March 19, 2020

Accepted: April 06, 2020

\begin{abstract}
This paper aimed to find factors of single candidate on Landak Election 2017. We did indepth interview and collected document and news from various sources. Data analysis was conducted with qualitative method and content analysis based on political recruitment theory. We found three important factors causing single candidate in Landak Election 2017, which were regulation, candidate, and political communication factors. The election was successfully done, but contrary to the spirit of democracy with competition as the value.
\end{abstract}

Keywords: single candidate; election; competition; political recruitment

\begin{abstract}
ABSTRAK
Tulisan ini bertujuan mencari faktor-faktor munculnya calon tunggal dalam Pilkada Landak tahun 2017. Untuk menemukan jawaban, penulis melakukan wawancara secara mendalam dengan para informan dan mengumpulkan dokumen dan berita dari berbagai sumber media. Data-data dianalisis dengan menggunakan analisis kualitatif dan analisis isi (content analysis) dengan basis teori kompetisi dalam pemilihan demokratis dan teori rekrutmen politik. Tulisan ini menemukan tiga faktor penting yang menentukan munculnya calon tunggal dalam Pilkada Landak tahun 2017, yaitu faktor regulasi, figur calon, dan komunikasi politik. Pilkada Landak dengan calon tunggal memang berlangsung sukses, namun tidak sejalan dengan prasyarat demokrasi pemilihan yang menekankan pentingnya kompetisi.
\end{abstract}

Kata Kunci: calon tunggal; pilkada; kompetisi; rekrutmen politik;

\section{PENDAHULUAN}

Secara sederhana konsep calon tunggal dapat didefinisikan sebagai suatu keadaan di mana di dalam Pemilihan Kepala Daerah (Pilkada) hanya ada satu pasangan calon yang ditetapkan oleh Komisi Pemilihan Umum Daerah (KPUD) sebagai pasangan calon kepala daerah. Konsep ini pertama kali muncul ketika dilaksanakannya Pilkada serentak 9 Desember 2015. Pada saat itu terdapat 269 daerah melaksanakan Pilkada dan terdapat tiga daerah yang memiliki calon tunggal, yaitu Kabupaten Blitar, Tasikmalaya, dan Timor Tengah Utara di Provinsi Nusa Tenggara Timur (NTT). Munculnya fenomena calon tunggal di tiga 
daerah pemilihan ini ternyata menimbulkan masalah serius dalam politik elektoral di Indonesia karena undang-undang Pilkada, yaitu UU No. 8 Tahun 2015 tentang Pemilihan Gubernur, Bupati dan Walikota belum mengatur tentang calon tunggal.

Dari sinilah wacana calon tunggal menghangat dan ramai diperbincangkan oleh banyak kalangan. Sebagian besar mengkhawatirkan masa depan demokrasi elektoral Indonesia. Seorang pakar komunikasi politik Effendi Gozali dan Yayasan Sakti Suryandaru mengajukan gugatan ke Mahkamah Konstitusi (MK) untuk uji materi Pasal 49, 50, 51. Materi gugatan mereka meminta MK membuat keputusan dibolehkannya pelaksanaan Pilkada dengan calon tunggal agar hak konstitusional para pemilih tetap bisa dilaksanakan. Hasilnya MK memutuskan penundaan pelaksanaan Pilkada di tiga daerah tersebut dengan mengeluarkan keputusan MK Nomor: 100/PUU-XIII/2015 (Kompas, 2015).

Perdebatan mengenai calon tunggal menghangat kembali pada saat Pilkada serentak tahun 2017. Penyebabnya terdapat sembilan daerah yang hanya memiliki satu pasangan calon, yaitu Kota Tebing Tinggi, Kabupaten Tulang Bawang Barat, Kabupaten Pati, Kabupaten Landak, Kabupaten Buton, Kabupaten Maluku Tengah, Kota Jayapura, Kabupaten Tambrauw, dan Kota Sorong (Liputan 6 , 2016). Pilkada serentak tahun 2017 diselenggarakan di 7 (tujuh) provinsi, 18 kota, dan 76 kabupaten di Indonesia. Pilkada ini memperebutkan 101 posisi kepala daerah dan setidaknya ada 337 pasangan calon yang bertarung.

Beranjak dari kecenderungan fenomena calon tunggal dalam Pilkada yang terus meningkat pemerintah setuju melakukan revisi terhadap UU No. 8 Tahun 2015. Bersama dengan DPR undang-undang ini dibahas. Hasilnya UU No. 8 tahun 2015 diganti menjadi UU No. 10 Tahun 2016 tentang Perubahan Kedua atas Undang-Undang Nomor 1 Tahun 2015 tentang Penetapan Peraturan Pemerintah Pengganti Undang-Undang Nomor 1 Tahun 2014 tentang Pemilihan Gubernur, Bupati, dan Walikota Menjadi Undang-Undang. Dengan disahkannya undang-undang No. 10 Tahun 2016, pelaksanaan Pilkada dengan calon tunggal di sembilan daerah sah dilaksanakan (Kompas, 2016).

Kabupaten Landak merupakan salah satu dari sembilan daerah yang melaksanakan Pilkada serentak dengan calon tunggal yang dilaksanakan pada tanggal 15 September 2017. Satu-satunya pasangan calon yang ditetapkan KPU Landak, yaitu Carolin Margret Natasa-Herculanus Heriadi yang diusung oleh PDIP beserta 11 partai koalisinya. Pilkada Landak tahun 2017 diikuti oleh 12 partai politik. Selain PDIP ada Partai Nasdem, PKB, PKS, Partai Golkar, Partai Gerindra, Partai Demokrat, PAN, PPP, Partai Hanura, PBB, dan PKPI. Terdapat sepuluh partai politik yang mendapatkan kursi di DPRD Landak periode 20172022 yang jumlahnya mencapai 35 kursi, sedangkan dua partai politik tidak memperoleh kursi. Kesepuluh partai politik yang memperoleh kursi, yaitu PDIP 11, Nasdem 5, Golkar dan Gerindra masing-masing 4, Demokrat 3, PKB, PAN, dan PKPI masing-masing 2, Hanura dan PPP masing-masing 1. Sedangkan PKS dan PBB tidak mendapatkan kursi oleh karena itu sikap kedua partai dalam koalisi bersifat mendukung karena tidak memiliki hak mengusung.

Dilihat dari komposisi perolehan kursi dan suara Pemilu Legislatif tahun 2014, PDIP merupakan satu-satunya partai yang memperoleh $20 \%$ kursi di DPRD, atau 25\% akumulasi perolehan suara sah. Hal ini berarti PDIP Landak memperoleh 11 kursi atau 31,4\% dari 35 kursi. Dengan demikian secara 
otomatis PDIP memenuhi syarat untuk mengusung calon sendiri, sedangkan partai-partai lainnya yang memperoleh kursi di bawah $20 \%$ bisa mengajukan calon apabila mereka membentuk koalisi yang memenuhi syarat ketentuan $20 \%$ kursi.

Pada tahapan pendaftaran calon sempat ada wacana pembentukan partai koalisi untuk mengusung pasangan calon menandingi PDIP. Partai koalisi dimaksud meliputi NasDem (5 kursi), Golkar (4 kursi), dan PAN (2 kursi) yang jika dijumlahkan 11 kursi memenuhi syarat pencalonan. Waktu itu muncul beberapa calon yang dijagokan diantaranya Vincencius (Kepala Dinas Pertanian dan Pertenakan), Syahdan Anggoi (ketua Koni Landak), Markus Amid (anggota DPRD Kalbar), Amuk Haryono Kader Nasdem, Ludis Mantan Sekda Landak, dan dr. Suryanto (Tribun Landak, 2016).

Dalam keputusan rapat koordinasi DPD Partai Golkar Landak tanggal 23 Juli 2016, memutuskan Vinsensius-dr. Suryanto sebagai pasangan bakal calon (Balon) Bupati dan Wakil Bupati Landak periode 2017-2022 yang akan mereka usung (Antara Kalbar, 2016). Sayangnya, upaya koalisi yang dimotori oleh Partai NasDem ini gagal di tengah jalan. Justru berbalik arah masuk dalam gerbong mendukung pasangan calon yang diusung oleh PDIP. Selain itu, wacana calon perseorangan (independen) sempat pula muncul, yaitu pasangan Vincencius dan dr. Suryanto.

Bagi masyarakat Kabupaten Landak yang multi etnis, agama, dan afiliasi politik, Pilkada dengan calon tunggal ini sebagai peristiwa politik unik karena baru pertama kali terjadi. Pada Pilkada 2006 dan 2011, masyarakat dihadapkan dengan alternatif pilihan yang menyediakan beberapa pasang calon. Para calon saling berkompetisi secara sehat untuk memperebutkan suara pemilih. Pesta demokrasi di daerah membawa suasana pesta yang kompetitif dan menghasilkan pemimpin yang terpilih secara demokratis.

Pilkada Landak 2017 yang hanya menyuguhkan satu pasangan calon menimbulkan kekhawatiran. Kekhawatiran tentang kemunduran demokrasi di daerah karena calon tunggal dinilai bertentangan dengan nilai-nilai demokrasi yang selama ini mereka pahami. Bagi KPUD Landak calon tunggal tidak bertentangan dengan demokrasi karena secara legal formal ada undang-undang yang memayunginya. Terlepas dari adanya perbedaan-perbedaan pendapat, Pilkada Landak dengan calon tunggal berlangsung dengan sukses. Kesuksesan ini ditandai dengan pelaksanaan Pilkada yang berlangsung aman dan damai serta tingginya tingkat partisipasi masyarakat yang ikut mencoblos. Berdasarkan penelusuran data yang kami lakukan kepada KPUD Landak, dari 257.222 pemilih tetap, sebanyak 237.354 orang pemilih yang menggunakan hak pilihnya atau sekitar $92 \%$.

Permasalahan dalam Pilkada dengan calon tunggal di Landak bukan pada persoalan pelaksanaannya yang aman dan damai dan tingkat partisipasi yang tinggi, tetapi pada jumlah calonnya yang apabila dihubungkan dengan teori demokrasi pemilihan (umum) janggal dan bertentangan. Dalam demokrasi pemilihan, salah satu syarat penting bagi berlangsungnya pemilihan umum secara demokratis adalah adanya kompetisi atau persaingan diantara para kandidat atau calon peserta (Schumpeter, 1950; Dahl, 1972). Padahal jika dilihat dari peta kekuatan politik kepartaian dan kotokohan individu di Landak seharusnya calon yang diusung bisa lebih dari satu. Dari sisi kepartaian 
maksimal bisa dua calon, sedangkan ketokohan bisa muncul satu calon perseorangan (calon independen).

Analisis bersifat spekulatif bermunculan diantaranya: PDIP yang dikenal sebagai partai kuat di Landak, sikap pragmatisme partai-partai politik, popularitas Karolin, ketokohan Cornelis yang kharismatik dan lain sebagainya. Terlepas dari berbagai macam spekulasi-analitik tersebut, penelitian ini ingin mencari secara lebih mendalam sebab-sebab kemunculan calon tunggal dalam Pilkada Landak tahun 2017.

Beranjak dari uraian di latar belakang masalah, peneliti memfokuskan penelitiannya pada faktor-faktor penyebab munculnya calon tunggal dalam Pemilihan Kepala Daerah (Pilkada) Kabupten Landak tahun 2017. Rumusan permasalahan yang diangkat dalam penelitian ini adalah: Mengapa dalam Pemilihan Kepala Daerah di Kabupaten Landak Tahun 2017 yang muncul hanya satu calon kepala daerah? Tulisan ini bertujuan mengetahui dan menganalisis faktor-faktor penyebab munculnya calon tunggal dalam Pilkada Kabupaten Landak tahun 2017.

\section{METODE PENELITIAN}

Penelitian ini menggunakan metode penelitian kualitatif eksplanatif. Penulis memfokuskan pada analisis isi (content analysis). Pengumpulan data dilakukan dengan menggunakan wawancara secara memdalam dengan informan dan proses studi literatur yang didapatkan melalui sumber seperti buku, dokumen, artikel dalam jurnal, dan sumber dari media cetak maupun artikel online. Validitas data dilakukan melalui triangulasi yang berasal dari sumbersumber data yang berbeda.

\section{HASIL DAN PEMBAHASAN \\ Teori Rekrutmen Politik}

Penjelasan teoritis hubungan pemilu dengan pergantian (sirkulasi) elit penguasa berasal dari pendekatan asal usul elit penguasa. Asumsi pendekatan elit penguasa bahwa elit berasal dari dan bertugas mewakili masyarakat luas dan elit penguasa yang digantikan kembali kepada lingkungan sosialnya. Dengan mengmbangkan teori Pareto tentang pergantian elit penguasa oleh elit bukan penguasa karena superioritasnya yang meningkat tajam, Kolabinska merumuskan tiga tipologi sirkulasi elit, yaitu: (1) anggota segmen elit penguasa berganti kedudukan sebagai penguasa; (2) warga non-elit direkrut atau mendapatkan posisi elit penguasa; dan (3) elit baru memenangkan pertarungan dengan elit penguasa dan kemudian menggantikannya (Bottomore, 1964, pp. 4849).

Pemilihan Kepala Daerah (Pilkada) selalu berkaitan dengan proses pencalonan kandidat untuk dipertarungkan dalam pemilihan. Calon-calon yang diusung lazimnya melalui beberapa tahapan untuk bisa sampai pada tahap dipertarungkan. Di negara-negara demokratis partai politik memegang peran penting dalam proses pencalonan kandidat. Peran penting itu terkait dengan salah satu fungsi klasik partai politik, yaitu melakukan rekrutmen politik.

Maksud dari pengaturan pencalonan kandidat tersebut di atas adalah agar dalam pelaksanaan Pilkada ada kompetisi calon, sehingga dapat dihasilkan kepala daerah yang berkualitas. Kepala Daerah yang memiliki kualitas baik diyakini mampu melaksanakan pemerintahan dengan baik pula. Dengan 
demikian kompetisi merupakan prasyarat penting bagi pelaksanaan Pilkada. Pilkada tanpa kompetisi menyalahi prinsip-prinsip demokrasi.

Teori rekrutmen politik berakar dari teori elit dan kelas yang dikemukakan oleh Karl Marx. Beberapa teoritisi elit seperti Robert Mitchel, Gaetano Mosca (1939), Vilfredo Pareto (1935), James Burnham (1941), C. Wright Mills (1956), dan T.B. Bottomore (1964), berekasi terhadap teori kelas Karl Marx. Dengan demikian, teori kelas dari Karl Marx memberikan sumbangsih besar bagi pembentukan teori elit secara utuh. Kemudian dari teori elit inilah muncul teori rekrutmen politik.

Gabriel A. Almond (Mas'oed \& MacAndrews, 1997, p. 50) memahami rekrutmen politik sebagai suatu proses yang memberikan kesempatan bagi rakyat untuk menyeleksi kegiatan-kegiatan politik dan jabatan pemerintah melalui penampilan dan media komunikasi, menjadi anggota oragnisasi, mencalonkan diri untuk jabatan tertentu, pendidikan, dan latihan. Mirriam Budiardjo (1996, p. 203) menyatakan bahwa rekrutmen politik adalah proses melalui mana partai mencari anggota baru dan mengajak orang yang berbakat untuk berpartisipasi dalam proses politik, menjamin kontinuitas dan kelestarian partai sekaligus sebagai sarana untuk menyeleksi calon-calon pimpinan.

Jack C. Plano (1985, p. 211) menjelaskan bahwa rekruitmen ada yang dikatagorikan sebagai rekrutmen sosial dan ada pula yang rekrutmen politik. Rekrutmen sosial adalah suatu proses pemilihan orang-orang untuk mengisi peranan dalam sistem sosial, sedangkan rekutmen politik adalah proses pengisian pada posisi formal (legal) seperti jabatan presiden dan anggota parlemen, serta peranan-peranan yang tidak formal seperti perekrutan aktivis dan propaganda (Plano, 1985, p. 211). Dengan demikian, partai politik sebagai institusi formal menjalankan fungsi rekrutmen dalam rangka pengisian jabatanjabatan politik.

Barbara Gidddes (1996, pp. 78-79) mengklasifikasikan sistem rekrutmen menjadi empat model:

1. Partisanship. Model ini merupakan model rekrutmen politik dari partai politik yang dinilai atas dasar loyalitas pada partai dan berusaha mengumpulkan partisan. Model ini kurang memperhatikan kompetisi.

2. Meriticratic. Model ini merupakan model rekrutmen politik dari kalangan yang memiliki kompetensi tinggi seperti teknokrat, pengusaha, guru, pekerja ahli, dan lain-lain.

3. Compartmentalizatioan. Model ini merupakan model rekrutmen politik yang didasarkan pada pengangkatan meritokratis informasi bagi posisiposisi yang dipertimbangkan sebagai penting bagi keberhasilan pragmatis, sambil pada saat yang sama memungkinkan untuk menggunakan pengangkatan-pengangkatan lain untuk dukungan jangka pendek dan pengembangan pengikut loyal.

4. Survival. Model ini merupakan model rekrutmen politik yang didasarkan pada prinsip balas jasa dan sumber daya pelamar serta cenderung patronase.

Menurut Lili Romli (2004, p. 19) proses rekrutmen politik dapat dilakukan dengan cara terbuka dan tertutup. Pertama, sistem rekrutmen politik terbuka. Dalam sistem ini warga negara diberi kesempatan yang seluas-luasnya untuk menduduki jabatan politik maupun pemerintahan asal meraka memenuhi syarat-syarat yang ditentukan dan memiliki bakat. Kedua, sistem rekrutmen 
politik tertutup. Dalam sistem ini ada batasan-batasan bagi warga negara. Hanya warga negara yang memenuhi syarat-syarat tertentu saja yang bisa menduduki jabatan politik dan pemerintahan, yaitu kawan-kawan akrab, pengusaha, individu-individu yang memiliki kesamaan agama, daearh, etnis, bahkan keluarga dari pihak penguasa.

Firmanzah (2011, p. 49) menjelaskan metode rekrutmen dan seleksi calon pimpinan yang ia maksudkan meliputi tiga aspek penting. Ketiga aspek dimaksud, yaitu aspek identifikasi, aspek kader, dan aspek metode rekrutmen, dan calon kader berkualitas. Ketiganya ini merupakan suatu rangkaian mekanis yang dimulai dari identifikasi kader, metode rekrutmen, dan pemilihan calon berkualitas. Proses seleksi pimpinan dimulai dari kegiatan melakukan identifikasi kader. Dalam hal ini siapa kader-kader yang dianggap potensial untuk dijadikan calon pimpinan. Tahap kedua adalah metode rekrutmen yang terkait dengan seperangkat aturan formal kepartaian. Untuk masing-masing partai politik berbeda dalam metode rekrutmennya, tetapi pada umumnya berkaitan dengan syarat-syarat administratif dan faktual. Sedangkan yang ketiga, yaitu calon kader berkualitas merupakan tahapan menentukan siapa calon partai yang dinilai berkualitas untuk dipertarungkan dalam pemilu atau untuk menduduki jabatan politik dan pemerintahan. Dalam menghasilkan keputusan partai politik mempertimbangkan sumber-sumber yang berasal dari dalam maupun luar partai politik.

\section{Peta Kekuatan Politik Kepartaian di Kabupaten Landak}

Melihat kekuatan politik kepartaian di Kabupaten Landak tidak bisa lepas dari konteks historis pemilu yang pernah dilangsungkan di Landak. Pemilu dimaksud meliputi Pemilu Legislatif dan Pemilihan Kepala Daerah (Pilkada). Pertarungan politik kepartaian dapat dilihat dari hasil pemilu yang diperoleh partai politik. Partai politik yang bertarung dalam pemilihan adalah partai-partai yang terdaftar secara resmi dan ditetapkan sebagai peserta pemilu.

Pada Pemilu Legislatif tahun 2014, ada 15 partai politik yang terdaftar sebagai peserta, dengan pembagian 12 partai politik berbasis nasional dan tiga partai politik berbasis lokal di Provinsi Nangro Aceh Darussalam (NAD). Keduabelas partai politik berbasis nasional meliputi Partai Nasdem, PKB, PKS, PDIP, Partai Golkar, Partai Gerindra, Partai Demokrat, PAN, PPP, Partai Hanura, PPB, dan PKPI. Sementara tiga parpol lokal di Aceh terdiri dari Partai Damai Aceh (PDA), Partai Nasional Aceh (PNA) dan Partai Aceh (PA).

Di Kabupaten Landak, kepesertaan partai politik dalam Pemilu Legislatif maupun Pilkada mengikuti partai politik berbasis nasional. Dengan demikian, keduabelas partai berbasis nasional sebagaimana yang disebutkan di atas merupakan peserta Pemilu Legislatif dan Pilkada. Para peserta Pemilu saling berkompetisi untuk menempati calon terbaik mereka di parlemen maupun di pemerintahan.

Di Landak, PDIP telah dikenal sebagai partai terkuat dan dominan. Sejak Pemilu, baik Pemilu Legislatif maupun Pemilu Kepala Daerah dilangsungkan, selalu menjadi partai pemenang. Pada Pilkada tahun 2006 misalnya PDIP unggul signifikan. Pasangan calon yang mereka usung, yiatu Cornelis yang berpasangan dengan Adrianus Asia Sidot keluar sebagai pemenang. Pada Pemilu Legilatif tahun 2014 perolehan suara PDIP jauh mengungguli partai-partai lainnya. Dalam tabel di bawah memperlihatkan PDIP memperoleh 11 kursi di DPRD. 
Tabel 1 - Jumlah Perolehan Suara dan Perolehan Kursi partai Politik pada Pemilu Legislatif Tahun 2014 di Kabupaten Landak

\begin{tabular}{clcc}
\hline No. & \multicolumn{1}{c}{ Nama Partai Politik } & $\begin{array}{c}\text { Perolehan } \\
\text { Suara }\end{array}$ & $\begin{array}{c}\text { Perolehan } \\
\text { Kursi }\end{array}$ \\
\hline 1 & Partai Nasional Demokrat (Nasdem) & 25.567 & 5 \\
\hline 2 & Partai Kebangkitan Bangsa (PKB) & 7.581 & 2 \\
\hline 3 & Partai Keadilan Sejahtera (PKS) & 4.910 & - \\
\hline 4 & Partai Demokrasi Indonesia Perjuangan (PDIP) & 66.270 & 11 \\
\hline 5 & Partai Golongan Karya (Golkar) & 23.218 & 4 \\
\hline 6 & Partai Gerakan Indonesia Raya (Gerindra) & 26.652 & 4 \\
\hline 7 & Partai Demokrat & 22.610 & 3 \\
\hline 8 & Partai Amanat Nasional (PAN) & 16.259 & 2 \\
\hline 9 & Partai Persatuan Pembangunan (PPP) & 4.378 & 1 \\
\hline 10 & Partai Hati Nurani Rakyat (Hanura) & 9.828 & 1 \\
\hline 11 & Partai Damai Aceh (PDA) & - & - \\
\hline 12 & Partai Nasional Aceh (PNA) & - & - \\
\hline 13 & Partai Aceh (PA) & - & - \\
\hline 14 & Partai Bulan Bintang (PBB) & 97 & - \\
\hline 15 & Partai Keadilan dan Persatuan Indonesia (PKPI) & 12.165 & 2 \\
\hline & Jumlah & $\mathbf{2 1 9 . 5 3 5}$ & $\mathbf{3 5}$ \\
\hline
\end{tabular}

Sumber: KPUD Kabupaten Landak 2014 (BPS Kabupaten Landak, 2016)

Tabel di atas menunjukkan PDIP unggul dengan 66.270 suara sah atau sekitar $30 \%$ dari total suara sah 219.535. Hasil ini sangat fantastis karena jauh meninggalkan perolehan suara partai-partai lainnya. Dari hasil ini jumlah kursi DPRD yang layak diperoleh oleh PDIP sebanyak 11 kursi atau sekitar $31 \%$ dari 35 kursi DPRD Landak. Dengan demikian, PDIP satu-satunya yang lolos Parlementary Threshold (PT) dan berhak mengusung calon sendiri dalam Pilkada berikutnya tanpa harus koalisi dengan partai lain. Sementara itu, partai lainnya jika ingin mengusung calon dalam Pilkada harus berkoalisi.

Masih dalam tabel di atas, perolehan suara partai politik yang cukup banyak secara berurutan diperoleh partai Gerindra (26.652), Nasdem (25.567), Golkar (23.218), dan Demokrat (22.610). Namun, perolehan suara yang cukup besar tidak serta merta memperoleh jumlah kursi yang besar pula. Hal ini dikarenakan pembagian kursi merujuk pada total suara partai secara nasional. Dalam tabel di atas terlihat perolehan kursi partai Nasdem sebanyak 5 kursi, sedangkan Gerindra hanya 4 kursi, padahal jumlah suara Gerindra melebihi suara Nasdem. Sebaliknya, Golkar dan Demokrat yang jumlah suaranya lebih kecil dari Gerindra memperoleh kursi yang jumlahnya sama, yaitu 4 kursi.

Jumlah kursi yang diperoleh oleh partai Nasdem, Gerindra, Golkar dan Demokrat masing-masing institusional tidak memenuhi Parlementry Threshold (PT). Dengan demikian, jika ingin mengusung calon bupati mereka harus berkoalisi untuk mencapai minimal 11 kursi sebagaimana yang diamanatkan oleh undang-undang Pilkada, yaitu UU No. 10 Tahun 2016.

Masih dalam tabel di atas, PBB, PKS, dan PPP memperoleh suara yang sangat menyedihkan yaitu PBB memperoleh sebanyak 97 suara, PKS sebanyak 4.910 suara, dan PPP sebanyak 4.378 suara. Padahal partai-partai ini termasuk partai yang dalam skala nasional cukup dikenal oleh masyarakat Indonesia. PPP 
masih beruntung memperoleh 1 kursi DPRD Landak, sementara PBB dan PKS sama sekali tidak. Fenomena ini tentu menarik jika ditelusuri lebih dalam. Apakah rendahnya elektabilitas partai-partai ini berkiatan dengan ideologi ketiga partai ini yang berbasis Islam? Sebagaimana diketahui, di Kabupaten Landak mayoritas penduduknya bergama Katholik dan Protestan, yaitu kurang lebih $80 \%$. Dalam konteks politik pemilihan, pilihan berdasarkan agama dan etnis merupakan suatu kewajaran. Sebagaimana yang juga terjadi di provinsi yang mayoritas penduduknya bergama Islam, kecenderungan perilaku pemilih lebih kepada partai-partai Islam.

Masih dalam tabel di atas, PKB yang "lebih dikenal" sebagai partai Islam, di Kabupaten Landak justru memperoleh kursi, yaitu 2 kursi. Mengapa hal ini tidak berlaku sama dengan partai berbasis Islam lainnya? Untuk diketahui bahwa PKB di bawah pimpinan Cak Imin (panggilan untuk ketua umumnya Muhaimin Iskandar) sebelum Pemilu 2014 mengeluarkan kebijakan membuka partai bagi semua kalangan dan hal ini sejalan dengan ideologi partainya yang berbasis Pancasila.

Peluang itu kemudian dimanfaatkan oleh individu-individu non muslim untuk menjadi anggota dan sarana mencalonkan diri sebagai wakil rakyat. Di beberapa kabupaten kota di Kalimantan Barat seperti di Kabupaten Sintang dan Landak, calon anggota DPRD yang duduk selain dari yang muslim juga dari individu non muslim. Sebagai sebuah strategi politik, kebijakan PKB yang secara terbuka membuka diri untuk kelompok non muslim, berhasil menjadikannya sebagai salah satu partai besar. PKB berhasil dalam melakukan adaptasi politik untuk survive.

\begin{tabular}{|c|c|c|c|c|}
\hline No. & Fraksi & Pria & Wanita & Jumlah \\
\hline 1 & Fraksi PDIP & 10 & 2 & 12 \\
\hline 2 & Fraksi Partai Nasdem & 5 & - & 5 \\
\hline 3 & Fraksi Partai Golkar & 4 & - & 4 \\
\hline 4 & Fraksi Partai Gerindra & 2 & 2 & 4 \\
\hline 5 & Fraksi Partai Demokrat & 3 & - & 3 \\
\hline 6 & Fraksi Anugrah & 4 & - & 4 \\
\hline \multirow[t]{2}{*}{7} & Fraksi Landak Berobah & 3 & - & 3 \\
\hline & Jumlah & 31 & 4 & 35 \\
\hline
\end{tabular}

Kekuatan politik kepartaian dapat pula dilihat dari perolehan suara dalam Pemilu Presiden (Pilpres) tahun 2014. Tabel di bawah ini menunjukkan distribusi suara pemilih kepada calon presiden yang diusung oleh partai politik. Pasangan Joko Widodo dan Jusuf Kalla yang diusung oleh koalisi partai, yaitu Koalisi Indonesia Hebat $(\mathrm{KIH})$, yang terdiri dari PDIP, Partai NasDem, Partai Hanura, PKB,dan PKPI mampu meraup suara sangat besar di Kabupaten Landak. Jumlah suara yang mereka peroleh sebanyak 195.610 suara dari 233.233 sah. Pasangan Prabowo Subianto dan Hatta Rajasa yang didukung oleh Koalisi Merah Putih (KMP), yang terdiri dari Partai Gerindra, Golkar, Demokrat, PPP, PAN, dan PKS, hanya mendapatkan 37.623 suara. Selisih suara ini sangat besar, yaitu 157.987 suara. 


\begin{tabular}{clcccc}
\multicolumn{5}{c}{ Tabel 3 - Jumlah Perolehan Suara Pasangan Calon Dalam Pemilu } \\
Presiden dan Wakil Presiden Tahun 2014 di Kabupaten Landak \\
\hline No. & $\begin{array}{c}\text { Nama } \\
\text { Kecamatan }\end{array}$ & \multicolumn{2}{c}{ Calon Pasangan } & $\begin{array}{c}\text { Jumlah } \\
\text { Suara } \\
\text { Sah }\end{array}$ & $\begin{array}{c}\text { Jumlah } \\
\text { Suara } \\
\text { Tidak Sah }\end{array}$ \\
\hline & & I & II & & \\
\hline 1 & Sebangki & 5.394 & 6.104 & 11.498 & 42 \\
\hline 2 & Ngabang & 9.248 & 31.249 & 40.497 & 224 \\
\hline 3 & Jelimpo & 2.358 & 15.321 & 17.679 & 161 \\
\hline 4 & Sengah Temila & 3.991 & 35.825 & 39.816 & 215 \\
\hline 5 & Mandor & 2.831 & 14.278 & 17.109 & 84 \\
\hline 6 & Menjalin & 1.025 & 10.957 & 11.982 & 42 \\
\hline 7 & Mempawah Hulu & 1.932 & 21.359 & 23.291 & 87 \\
\hline 8 & Sompak & 993 & 9.408 & 10.401 & 79 \\
\hline 9 & Menyuke & 2.869 & 16.176 & 19.045 & 183 \\
\hline 10 & Banyuke Hulu & 781 & 7.877 & 8.658 & 50 \\
\hline 11 & Meranti & 1.057 & 5.511 & 6.568 & 81 \\
\hline 12 & Kuala Behe & 2.280 & 8.409 & 10.689 & 53 \\
\hline 13 & Air Besar & 2.864 & 13.136 & 16.000 & 110 \\
\hline & Jumlah & $\mathbf{3 7 . 6 2 3}$ & $\mathbf{1 9 5 . 6 1 0}$ & $\mathbf{2 3 3 . 2 3 3}$ & $\mathbf{1 . 4 1 1}$ \\
\hline Sum & &
\end{tabular}

Sumber: KPUD Kabupaten Landak 2014 (BPS Kabupaten Landak, 2016)

Keterangan: I (H. Prabowo Subianto-Ir.H.M. Hatta Rajasa); II (Ir. H. Joko WidodoDrs.H.M. Jusuf Kalla).

Tabel di atas menunjukkan bahwa dari 13 kecamatan yang ada tidak ada satu kecamatanpun pasangan Prabowo-Hatta mengungguli suara pasangan Jokowi-Kalla. Bahkan di kota Ngabang yang pluralitas penduduknya lebih dominan, pasangan Prabowo-Hatta hanya mampu mendulang 9.248 suara. Apalagi di kecamatan lain yang homogenitas penduduknya lebih tampak.

Perolehan suara yang fantastis ini tentu tidak terlepas dari eksistensi PDIP Kalimantan Barat yang memang dikenal sebagai partai terbesar di Kalimantan Barat. Di Kabuputen Landak, PDIP adalah 'rumah politik' bagi partai ini. Dari pemilihan ke pemilihan tidak ada satu partaipun yang mampu mengungguli PDIP. Perbincangan khalayak jika menyangkut kekuatan PDIP di Landak selalu mengatakan "mana mampu lawan" (seng ada lawan dalam bahasa orang timur). Di masyarakat Dayak Kalimantan Barat pada umumnya PDIP sering disinonimkan dengan Partai Dayak Indonesia Perjuangan atau mereka sering mengatakan "partai kitai (kita)".

Perubahan sistem Pemilu dari Pemilu tidak langsung oleh rakyat menjadi Pemilu langsung oleh rakyat, atau dari sistem proporsional tertutup ke sistem proporsional terbuka, membawa angin perubahan baru dalam Pilkada di Kabupaten Landak. Sejak Pilkada dilaksanakan di Kabupaten Landak tahun 2006 yang berdasarkan pada UU No.32 Tahun 2004 tentang Pemerintahan Daerah dan PP No. 6 Tahun 2005, PDIP telah muncul sebagai partai terkuat di Kabupaten Landak. Pada Pilkada pertama kali tahun 2006 itu, putra Dayak Drs. Cornelis, MH yang diusung oleh PDIP menang telak di seluruh kecamatan yang ada. Ia menjadi bupati pertama hasil dari Pilkada langsung oleh rakyat untuk masa bakti 2006-2011. Namun, Cornelis hanya menjalani tugasnya 2 tahun saja (2006-2008) dikarenakan, ia lewat PDIP, dicalonkan sebagai calon Gubernur 
Kalimantan Barat (Kalbar) untuk bertarung dalam Pemilihan Gubernur (Pilgub) Kalbar tahun 2008. Dalam Pilgub tahun 2008, Cornelis yang berpasangan dengan Christiandy Sanjaya terpilih sebagai pasangan gubernur Kalbar periode 2008-2013.

\section{Peta Kekuatan Politik Individu di Kabupaten Landak}

Kekuatan politik individu dalam penelitian ini adalah kekuatan personal dari seorang tokoh politik lokal di Kabupaten Landak. Di Kabupaten Landak peta kekuatan politik individu dalam pemilihan umum bupati dapat ditelusuri dari Pilkada-Pilkada sebelumnya hingga dilaksanakannya Pilkada serempak tahun 2017 baru lalu. Dari data-data tersebut dapat disimpulkan terdapat beberapa kekuatan politik individu diantaranya Drs. Cornelis, M.H., Dr. Drs. Adrianus Asia Sidot, M.Si., Herculanus Heriadi, SE., Syahdan Angoi, Karolin Margaret Natasa. Masing-masing kekuatan individu tersebut berbeda dalam hal kualitas maupun kuantitas, tetapi nama-nama tersebut dalam peta politik lokal cukup berpengaruh dan menentukan.

\section{Faktor-Faktor yang Mempengaruhi Munculnya Calon Tunggal Faktor Regulasi}

Faktor regulasi merupakan faktor legal formal munculnya calon tunggal dalam Pilakda Landak tahun 2017. Seandainya pemerintah dan DPR tidak merevisi undang-undang Pilkada, yaitu Undang-Undang No. 8 Tahun 2015 dan mensahkannya menjadi Undang-Undang No.10 Tahun 2016, Pilkada dengan calon tunggal tidak dapat dilaksanakan. Undang-Undang No.10 Tahun 2016 adalah undang-undang tentang Perubahan Kedua atas Undang-Undang Nomor 1 Tahun 2015 tentang Penetapan Peraturan Pemerintah Pengganti UndangUndang Nomor 1 Tahun 2014 tentang Pemilihan Gubernur, Bupati, dan Walikota Menjadi Undang-Undang.

Dalam undang-undang No.10 Tahun 2016 Pasal 54C ayat 1 jelas menyebutkan bahwa Pilkada dengan calon tunggal dapat dilaksanakan apabila memenuhi kondisi-kondisi sebagaimana disebutkan dalam Pasal 54C ayat 1 (point a, b, c, d, dan e). Kondisi-kondisi yang dimaksudkan diantaranya: (1) Setelah terjadi penundaan hingga berakhirnya masa perpanjangan pendaftaran hanya ada satu pasngan calon, baik karena satu paslon yang mendaftar maupun dua paslon mendaftar, tetapi yang dinyatakan memenuhi syarat hanya satu (point a \& b); (2) Berhalangan tetap, baik sejak masa penetapan maupun masa masa kampanye, dan tidak ada paslon pengganti yang diusulkan oleh parpol (Point c \& d); (3) Terkena sanksi pembatalan (point e).

Sejak dibukanya pendafataran pasangan calon pada tanggal 21-23 September 2016 hanya ada satu pasangan calon yang didaftarkan oleh gabungan partai politik (PDIP dan lainnya), yaitu Karolin Margret NatasaHerculanus Heriady. Meskipun KPUD Landak memperpanjang masa pendaftaran selama 3 hari dari tanggal 29 September-1 Oktober 2016, setelah sebelumnya menunda tahapan selama 2 hari, yaitu tanggal 24-25 September 2016 dan melakukan sosialisasi selama 3 hari tanggal 26-28 September 2016, tetap saja tidak ada yang mendafatar selain Karolin-Heriady (Tribun Landak, 2016). Atas dasar itu KPUD Landak menetapkan Karolin-Heriady sebagai pasangan calon tunggal pada tanggal 24 Oktober 2016 berdasarkan Keputusan Nomor: 48/Kpts/KPU-Kab.019.435682/2016 tentang Penetapan Pemilihan 
Bupati dan Wakil Bupati Landak Tahun 2017 Dengan Satu Pasangan Calon (The Tanjungpuratimes, 2016).

Mengenai calon tunggal dalam Pilkada Landak tahun 2017, Ketua KPUD Landak, Lomon, mengatakan bahwa munculnya calon tunggal dalam Pilkada Landak dipengaruhi oleh faktor regulasi, yaitu disahkannya UU No. 10 Tahun 2016 tentang Perubahan kedua Undang-undang Nomor 1 Tahun 2015 tentang Penetapan Peraturan Pemerintah Pengganti Undang-undang Nomor 1 Tahun 2014 tentang Pemilihan Gubernur, Bupati dan Walikota. Lebih lanjut dalam wawancara beliau mengatakan bahwa seandainya undang-undang ini tidak ada, tentu pihak KPUD tidak akan berani menyelenggarakan Pilkada dengan calon tunggal. KPUD Landak bekerja berdasarkan aturan yang sudah ditentukan dari pusat dan mereka di daerah tinggal melaksanakannya dan jika ada hal-hal yang mesti dibuat terkait keputusan, maka KPUD Landak pasti membuatnya sebagai pelaksana teknis.

Untuk memperlancar pelaksanaan Pilkada dengan calon tunggal KPU Kabupaten Landak mengeluarkan beberapa keputusan sebagai berikut:

1. Keputusan Nomor: 48/Kpts/KPU-Kab.019.435682/2016 tentang Penetapan Pemilihan Bupati dan Wakil Bupati Landak Tahun 2017 Dengan Satu Pasangan Calon. Keputusan ini ditetapkan pada tanggal 24 Oktober 2016.

2. Keputusan Nomor: 42/Kpts/KPU-Kab.019.435682/2016 tentang perubahan Ketiga Keputusan Komisi Pemilihan Umum Kabupaten Landak Nomor: 3/Kpts/KPU-Kab.091.435682/2016 tentang Tahapan, Program dan Jadwal pemilihan Bupati dan Wakil Bupati Landak Tahun 2017;

3. Keputusan Nomor: 47/Kpts/KPU-Kab.019.435682/2016 tentang perubahan Ketiga Keputusan Komisi Pemilihan Umum Kabupaten Landak Nomor: 3/Kpts/KPU-Kab.091.435682/2016 tentang Penetapan pasangan Calon yang Memenuhi Syarat Sebagai Peserta Pemilihan Bupati dan Wakil Bupati Landak Tahun 2017.

Faktor regulasi pelaksanaan Pilkada dengan calon tunggal dilihat dari sisi hukum sah adanya. Bagaiamanapun Pilkada dengan calon tunggal apabila tidak dilandasi oleh aturan hukum tidak bisa dilaksanakan. Pertama, KPUD Landak merupakan pelaksana tugas pemerintah yang diikat oleh aturan-aturan hukum dalam pelaksanaan tugasnya. Kedua, dari sisi pemerintah, mengingat pada tahun 2015 beberapa daerah dengan calon tunggal ditunda pelaksanaannya, maka tidak mungkin pada Pilakda tahun 2017 dengan calon tunggal mesti ditunda lagi. Jika terus menurus ditunda, maka kebijakan pemerintah tentang Pilkada serentak yang harus tuntas pada tahun 2019 dipastikan tidak akan terwujud.

Dengan demikian atas pertimbangan tersebut, maka Pilakda tahun 2017 dengan calon tunggal tetap dilaksanakan dengan ketentuan tetap menggunakan dua kotak suara. Satu kotak suara untuk calon tunggal dan satunya kotak kosong tanpa calon bagi pemilih yang memilih bukan calon tunggal. Kotak kosong ini disisi lain sebagai indikator untuk melihat legitimasi calon tunggal jika ia terpilih atau tidak.

Dari sisi teori demokrasi, jelas bahwa tidak dikenal istilah calon tunggal dalam pelaksanaan Pemilu atau Pilkada. Salah satu prinsip penting demokrasi pemilihan adalah adanya kompetisi atau persaiangan. Kompetisi jelas menunjukkan pada tersedianya calon lebih dari satu orang, bisa dua, tiga atau 
lebih. Pemilihan demokratis tanpa kompetisi tidak ubahnya sistem pemilihan dalam sistem otoriter. Dengan demikian jelas bahwa Pilkada dengan calon tunggal bertentangan dengan prinsip dasar demokrasi. Dapat dikatakan suatu keadaan yang anti demokrasi. Hal ini tentu tidak sehat bagi perkembangan demokrasi di Indonesia. Proses pembangunan demokrasi yang sedang kita jalankan bukan mustahil akan kembali ke sistem otoriterianisme, meskipun otorianisme yang dimaksud adalah otoriterianisme gaya baru (neootoriterianisme), yaitu wajahnya demokrasi tetapi isinya otoriterianisme.

\section{Faktor Figur Karolin Margret Natasa}

Tidak bisa dipungkiri sosok Karolin berpengaruh kuat pada munculnya calon tunggal dalam Pilkada Landak tahun 2017. Ia adalah figur politik muda yang dikenal luas di Landak dan Kalimantan Barat umumnya. Di Landak ketika nama ini disebutkan nyaris tidak ada yang tidak kenal. Semua orang mengenal dirinya dengan baik. Orang-orang mengenal Karolin bukan saja sebagai anggota DPR RI Dapil Kalimantan Barat, tetapi sebagai putri dari Gubernur Kalimantan Barat, Cornelis. Karolin juga dikenal karena ciri-ciri yang melekat dalam dirinya selalu dikenal orang sebagai politisi muda yang cantik, baik, pintar, dan merakyat.

Berdasarkan hasil wawancara dengan ketua PDIP Landak mengatakan bahwa Karolin merupakan sosok yang memang merakyat dan dikenal secara luas oleh masyarakat Landak. Menurutnya, orang-orang mengenalnya bukan semata sebagai anak Cornelis, tetapi karena selama ini ia banyak bersentuhan dengan masyarakat. Misalnya, ketika beliau melakukan reses dan kampanye politik, dilakukannya dengan bersungguh-sungguh dalam melakukan tugas resesnya dan kampanye sampai ke kampung-kampung pedalaman Landak. Padahal ketika melakukan reses Karolin sedang dalam kondisi hamil, di mana harus melewati jalan di kampung-kampung yang rusak dan butuh waktu berjam-jam perjalanan pulang pergi.

Terkait dengan popularitas Karolin yang dikaitkan dengan ketokohan Cornelis, Ketua PDIP Landak mengatakan bahwa pengaruh itu pasti ada bagaimanapun Karolin adalah anaknya Cornelis. Tidak mungkin hubungan sedarah ini tidak memiliki pengaruh. Seperti kata pepatah tua mengatakan buah jatuh tidak jauh dari pohonnya. Namun, pengaruh itu bukan pengaruh yang dominan serta merta menjadikan Karolin politisi yang sukses. Kesuksesan Karolin lebih banyak dipengaruhi oleh semangat dan kesungguhannya dalam berpolitik dan selalu dekat dengan masyarakat.

Senanda dengan ketua Umum PDIP Landak, seorang anggota Fraksi Landak Berobah (dari PKPI) mengatakan bahwa sosok Karolin memang sosok yang dikenal oleh masyarakat di Landak dan Kalimantan Barat pada umumnya. Menurut analisanya untuk di Landak susah mencari tokoh setenar Karolin. Apalagi menurutnya Karolin adalah putri dari gubernur Kalimantan Barat, Cornelis. Makanya di Pilkada Landak 2017 hanya ada calon tunggal karena jika ada calon lainpun yang muncul dipastikan kalah. Hanya buang-buang uang dan tenaga.

Salah seorang informan yang berprofesi sebagai pemilik warung makan yang kami wawancarai di Pasar Landak mengatakan bahwa popularitas Karolin di Landak memang dikenal orang di sini. Namun, ia mengatakan bahwa tidak tahu jika di tempat lain. Senada dengan itu beberapa orang mahasiswa FISIP 
Untan asal Landak yang kami wawancarai tentang ketokohan Karolin mengatakan bahwa memang kalau untuk di Landak Karolin dikenal sebagai tokoh yang merakyat. Mereka menambahkan tidak heran jika Karolin muncul sebagai calon tunggal dalam Pilkada tahun 2017. Justru menurut mereka Karolin pasti menjadi bupati Landak periode 2017-2022. Adapula hal menarik yang disampaikan oleh informan mahasiswa ini, yaitu ketidak setujuan mereka dengan kecenderungan munculnya dinasti politik di Landak karena menurut mereka menghambat demokrasi dan hak-hak politik seseorang. Di Landak sebetulnya masih banyak tokoh yang berpengaruh dan mampu membangun Landak, tetapi karena tidak memiliki perahu partai dan uang tidak bisa mencalonkan dirinya.

Dari beberapa hasil wawancara tersebut di atas dapat disimpulkan bahwa bagi masyarakat di Kabupaten Landak sosok Karolin figur yang sangat dikenal dan berpengaruh luas. Bukan semata-mata dikenal sebagai putri dari gubernur Kalimantan Barat, Cornelis, tetapi karena sepak terjang politiknya selama ini dirasakan manfaatnya oleh masyarakat di Landak.

Figur Karolin yang terkenal didukung pula oleh data-data hasil pemilu legislatif dan kepesertaannya di organisasi sosial keagamaan di Landak. Pertama, fakta tentang karir politiknya di DPR RI. Ketika ia memutuskan untuk bertarung sebagai calon anggota DPR RI Dapil Kalimantan Barat pada Pemilihan Umum Legislatif tahun 2009, elektabilitas Karolin mampu menempati urutan ketiga suara terbanyak nasional. Masyarakat Kalimantan Barat yang memilihnya mencapai 222.021 suara pemilih (Merdeka.com, 2014). Sedangkan, pada Pemilihan Umum Legislatif tahun 2014, elektabilitasnya mampu menempatkan perolehan suaranya terbanyak secara nasional (se-Indonesia). Adapun jumlah suara yang dia peroleh sebanyak 397.481 suara (Detik News, 2014). Tentu sebagai pendatang baru dalam dunia politik nasional hasil yang dia peroleh sungguh fantastis. Hasil ini juga menunjukkan bahwa popularitas Karolin di Kalimantan Barat memang kuat.

Kedua, fakta tentang keaktifannya di berbagai organisasi sosial kemasyarakat dan keagamaan. Karolin dikenal aktif di organisasi sosial kemasyarakat dan keagamaan, baik di Landak, Kalimantan Barat, maupun Nasional. Ia perempuan pertama yang menjabat sebagai Ketua Umum Organisasi Kepemudaan Pemuda Katolik. Pernah menjadi Ketua Pangda ISSI Kalbar, Ketua Taruna Merah Putih, Pengurus Pusat Ikatan Sarjana Katolik (ISKA) dan duta BKKBN. Di Parlemen pusat, ia aktif mendukung program BPJS terutama untuk masyarakat perbatasan Kalimantan Barat dan mewujudkan terbangunnya rumah sakit perbatasan. Sebagai politisi muda yang berusia 34 tahun, karir politiknya masih terbuka lebar, baik di Landak, Kalimantan Barat, maupun nasional pada umumnya.

Ketika, fakta bahwa survei tentang calon bupati Landak menempatkan Karolin Margret Natasa sebagai calon terkuat di Pilkada Landak. Survei internal yang dilakukan oleh PDIP pada pertengahan tahun 2016 menunjukan hasil bahwa Karolin merupakan bakal calon yang baik elektabilitasnya maupun popularitasnya berada di level paling atas. Survei-survei dari lembaga lain juga menunjukkan hasil yang sama. Ketiga fakta di atas sejalan dengan pendapat Sa'ban (2019, p. 64) yang menyebutkan dalam penelitiannya bahwa salah satu faktor yang mempengaruhi partisipasi politik adalah faktor karakteristik pribadi. 
Selain, faktor perangsang politik, karakteristik sosial, dan keadaan politik (Sa'ban, 2019).

\section{Faktor Komunikasi Politik}

Faktor komunikasi politik sangat berpengaruh dalam munculnya calon tunggal dalam Pilkada Landak tahun 2017. Komunikasi politik yang bersifat intensif dan efektif, dilakukan oleh Cornelis selaku ketua DPD PDIP Kalimantan Barat. Sebagai tokoh sentral di PDIP Kalimantan Barat, Cornelis berhasil membangun komunikasi politik dengan DPD dan DPC partai politik di Kalimantan Barat. Upaya ini terus dilanjutkan sampai ke pusat.

Pada tanggal 9 September 2017 di Jakarta, Cornelis selaku ketua DPD PDIP Kalimantan Barat bertemu dengan Ketua Umum Partai Nasdem, Surya Paloh bertempat di kantor DPP partai Nasdem Jalan Gondangdia Jakarta Pusat. Dalam pertemuan itu Cornelis menyampaikan keinginan untuk berkoalisi dengan Partai Nasdem dalam Pilkada Landak tahun 2017. Surya Paloh memberikan apresiasi komunikasi politik yang dilakukan oleh Cornelis dan menyatakan bahwa Karolin Margret Natasa dianggap pantas untuk memimpin Kabupaten Landak periode ke depan karena memiliki elektabilitas, integritas, dan kualitas yang tinggi. Dengan kriteria itu, partai Nasdem tidak tidak ragu untuk menjatuhkan dukungan kepada anggota DPR RI Dapil Kalimantan Barat peraih suara terbanyak se-Indonesia itu. Partai Nasdem Nasdem juga menilai Karolin Margret Natasa paling pantas untuk mengemban mandat sebagai bupati Landak periode 2017-2022.

Selain dengan Nasdem, PDI Perjuangan juga melakukan komunikasi politik dengan Partai Demokrat, Partai Gerindra, dan Partai Golkar. Di Jakarta, Cornelis dan Karolin bertemu dengan ketua DPD Partai Demokrat Albert Yaputra bersama pengurus DPP Partai Demokrat. Dala,m pertemuan itu partai Demokrat dipastikan mendukung pasangan calon dr. Karolin Margret Natasa dan Herculanus Heriadi, SE di Pilkada Kabupaten Landak Februari 2017. Albert Yaputra adalah anggota DPR RI dari Partai demokrat Daerah pemilihan Kalimantan Barat.

DPD PDIP juga melakukan komunikasi politik dengan partai Golkar. Ketua DPD Partai Golkar, Siyus, mengatakan bahwa memang ada komunikasi politik yang dilakukan oleh Ketua DPD PDIP Kalimantan Barat dengan DPP Partai Golkar di Jakarta. Siyus mengatakan bahwa pertemuan itu menghasilkan keputusan DPP Partai Golkar mendukung sepenuhnya Karolin Margret Natasa maju sebagai calon bupati Landak tahun 2017. Keputusan ini merupakan hasil Munas Partai Golkar. Dengan dikeluarkannnya keputusan DPP tersebut, maka DPD II Partai golkar besarta DPC mendukung sepenuhnya langkah politik yang diambil oleh DPP Partai Golkar. Memang dalam Pilkada tahun 2017 lalu, Partai Golkar menaruh perhatian serius untuk Landak dan Singkawang, seperti yang dikatakan oleh Sekretaris DPP Partai Golkar, Idrus Marham yakin bahwa calon yang mereka jagokan akan menag dalam Pilkada di dua daerah tersebut (Suara Pemred Kalbar, 2016).

DPD PDIP Kalimantan Barat juga melakukan komunikasi politik dengan Partai Gerindra. Partai Gerindra merupakan peraih suara terbesar kedua dalam Pemilihan Umum Legislatif tahun 2014 di Kabupaten Landak. Hasil dari komunikasi politik tersebut adalah DPD Partai Gerindra mendukung Karolin Magret Natasa sebagai calon bupati dalam Pilkada Landak tahun 2017. Memang 
sebelumnya, DPC Partai Gerindra Kabupaten Landak telah memutuskan untuk mengusung pasangan calon Vinsensius dan Syahdan Anggoi berdasarkan Surat Keputusan DPC Partai Gerindra Kabupaten Landak Nomor: 1330/DPC.GERINDRA/LDK/VII/2016. Surat Keputusan ini didukung oleh 10 PAC dari 13 PAC di Kabupaten Landak. Tetapi faktanya kemudian DPP Partai Gerindra memutuskan mendukung Karolin Margret Natasa untuk maju dalam Pilkada Landak tahun 2017.

\section{PENUTUP \\ Simpulan}

Berdasarkan hasil pembahasan yang sudah dipaparkan terdapat beberapa kesimpulan dalam tulisan ini. Pertama, penulis menemukan faktor regulasi sebagai faktor kuat yang mendorong munculnya calon tunggal dalam Pilkada Landak tahun 2017. Kedua, ditemukan bukti-bukti yang kuat bahwa Karolin Margaret sebagai figur kuat dan berpengaruh di Kabupaten Landak yang ditunjang oleh karir politik dan keaktifan beliau di berbagai organisasi sosial kemasyarakat dan keagamaan di tingkat nasional maupun lokal serta hasil survei elektabilitas awal yang sangat tinggi. Ketiga, penulis menemukan faktor komunikasi politik yang dilakukan oleh ketua DPD PDIP Kalimantan Barat, Cornelis dan timsesnya berlangsung sangat efektif, sehingga mendorong munculnya calon tunggal dalam Pilkada Landak tahun 2017.

\section{Saran}

Mengacu pada simpulan tersebut, penulis menyarankan pelaksanaan pilkada harus mengutamakan proses kompetisi. Untuk menuju hal tersebut, partai politik secara keseluruhan harus mulai memperbaiki mekanisme rekrutmen politik agar mampu menjaring kader-kader potensial. Pendidikan politik juga perlu diperbaiki agar citra partai politik di mata para pemuda menjadi lebih baik. Hal ini juga ditujukan agar calon-calon potensial di luar lingkaran dalam partai politik dapat bermunculan.

\section{DAFTAR PUSTAKA}

Antara Kalbar. (2016, Juli 27). Golkar Landak Usulkan Pasangan VinsensiusJulianto Pada Pilkada. Retrieved from Antara Kalbar: https: / / kalbar.antaranews.com/berita/342062/golkar-landak-usulkanpasangan-vinsensius-julianto-pada-pilkada

Bottomore, T. (1964). Elites and Society. London: Pinguin Books.

BPS Kabupaten Landak. (2016). Kabupaten Landak Dalam Angka. Ngabang: BPS Kabupaten Landak.

Budiardjo, M. (1996). Demokrasi di Indonesia Demokrasi Parlementer dan Demokrasi Pancasila. Jakarta: PT. Gramedia Pustaka Utama.

Dahl, R. (1972). Polyarchy: Participation and Opposition. New Haven, CT: Yale University Press.

Detik News. (2014, Mei 14). Caleg PDIP Karolin Margret Natasa Raih Suara Tertinggi, Libas Puan dan Ibas. Retrieved from detiknews: https://news.detik.com/berita/2582724/caleg-pdip-karolin-margretnatasa-raih-suara-tertinggi-libas-puan-dan-ibas?n992204fksberitadsfdsf=

Firmanzah. (2011). Mengelola Partai Politik. Jakarta: Yayasan Pustaka Obor Indonesia. 
Giddes, B. (1996). Politician's Dilema: Building State Capacity in Latin America. California: University California Press.

Kompas. (2015, September 29). Hari Ini, MK Putuskan Uji Materi Calon Tunggal dalam Pilkada. Retrieved from Kompas.com: https:// nasional.kompas.com/read/2015/09/29/08291171/Hari.Ini.MK. Putuskan.Uji.Materi.Calon.Tunggal.dalam.Pilkada.

Kompas. (2016, Juni 2). Ini Poin-poin yang Disahkan dalam Revisi UU Pilkada. Retrieved from Kompas.com: https://nasional.kompas.com/read/2016/06/02/17322641/ini.poinpoin.yang.disahkan.dalam.revisi.uu.pilkada.?page $=$ all

Liputan 6 . (2016, Februari 15). Ini 101 Daerah yang Gelar Pilkada Serentak 2017. Retrieved from Liputan6.com: https://m.liputan6.com/pilkada/read/2436435/ini-101-daerah-yanggelar-pilkada-serentak-2017

Mas'oed, M., \& MacAndrews, C. (1997). Perbandingan Sistem Politik. (Cetakan 14 ed.). Yogyakarta: Gajah Mada University Press.

Merdeka.com. (2014, Mei 15). Profil 5 anggota DPR dengan suara terbanyak. Retrieved from Merdeka.com: https://www.merdeka.com/politik/profil-5anggota-dpr-dengan-suara-terbanyak.html

Plano, J. C. (1985). Kamus Analisa Politik. Jakarta: Rajawali.

Romli, L. (2004). Demokrasi Dalam Bayang-Bayang Kekuatan Jawara Studi Kasus Pencalonan Caleg di Provinsi Banten 2004. Jakarta: LIPI.

Sa'ban, L. A. (2019, October). Partisipasi Politik Masyarakat dalam Pemilihan Kepala Daerah Kota Baubau. Journal of Government and Political Studies, 2(2), 59-67.

Schumpeter, J. (1950). Capitalism, Socialism and Democracy. New York: Herper \& Row.

Suara Pemred Kalbar. (2016, September 16). DPD II Partai Golkar Kabupaten landak Usung Karolin. Retrieved from Suara Pemred Kalbar: https://www.suarapemredkalbar.com/berita/landak/2016/09/16/akhir nya-dpd-ii-partai-golkar-kabupaten-landak-usung-karolin

The Tanjungpuratimes. (2016, September 28). Pendaftaran Paslon Pilkada Landak Diperpanjang. Retrieved from thetanjungpuratimes.com: https: / thetanjungpuratimes.com/2016/09/28/pendaftaran-paslonpilkada-landak-diperpanjang/

Tribun Landak. (2016, Oktober 4). Hanya Satu Paslon Mendaftar, Tahapan Ini Dilakukan KPU pada Pilkada Landak 2017. Retrieved from Tribunlandak.com: https: / pontianak.tribunnews.com/2016/10/04/hanya-satu-paslonmendaftar-tahapan-ini-dilakukan-kpu-pada-pilkada-landak-2017

Tribun Landak. (2016, Maret 21). Nama Nama Yang Kembalikan Formulir Bakal Calon Bupati Dan Wabup ke Partai NasDem Landak. Retrieved from Tribunlandak.com:

https: / pontianak.tribunnews.com/2016/03/21/nama-nama-yangkembalikan-formulir-bakal-calon-bupati-dan-wabup-ke-partai-nasdemlandak

Undang-undang Nomor: 2 Tahun 2011 tentang Partai Politik.

Undang-undang Nomor: 8 Tahun 2015 tentang Perubahan Pertama Penetapan Peraturan Pemerintah Pengganti Undang-Undang Nomor 1 Tahun 2014 
tentang Pemilihan Gubernur, Bupati, dan Walikota Menjadi UndangUndang.

Undang-undang Nomor: 10 Tahun 2016 tentang Perubahan Kedua Penetapan Peraturan Pemerintah Pengganti Undang-Undang Nomor 1 Tahun 2014 tentang Pemilihan Gubernur, Bupati, dan Walikota Menjadi UndangUndang. 